\title{
An Empirical Formula to Calculate Deferred Taxes in Balance Sheet Consolidation
}

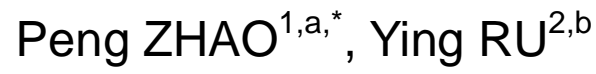 \\ ${ }^{1}$ Financial Management Department, Yinxing Hospitality Management College, Hongguang, Pixian, \\ Chengdu, 611743, China \\ ${ }^{2}$ Business School, Sichuan University, Wangjiang Road, Chengdu, 610064, China \\ aroc268@163.com, b840679388@qq.com \\ ${ }^{*}$ Corresponding author
}

Keywords: Consolidated balance sheet, Temporary differences, Deferred income tax assets, Deferred income tax liabilities, Offset entries.

\begin{abstract}
In the process of balance sheet combination, to confirm the amount of deferred income taxes offset entries quickly at any given time may need a concise method. An empirical formula was given on the basis of some relative principles. Three numerical examples about the internal inventories, fixed assets transactions and accounts receivable\& payable were discussed to testify the correctness and effectiveness of the formula. Finally, we draw the conclusion that the formula can deal with the sum of deferred income taxes offset entries quickly as expected.
\end{abstract}

\section{Introduction}

It is rather tedious and error-prone to eliminate deferred taxes in the balance sheet consolidation [1]. Deferred taxes associate with inventories, fixed assets, receivable\& payable accounts, etc . We can get a correct offset entry heavily relying on the correctness of all the former ones and it is also hard to remember so many classes caused by the above mentioned conditions efficiently for abecedarians. Therefore, a concise and easy operational method to deal with deferred taxes may become important and meaningful in practice.

The purpose of this paper was to give a kind of offset entry fast processing method through an empirical formula which could computerize deferred taxes resulted from the inventories, fixed assets and receivable\& payable accounts quickly. After the principle statement of the formula, some applying cases were explained immediately.

\section{Empirical formula and principle}

\section{Empirical formula}

We can calculate temporary differences [2] at any given time by the Eq. 1 .

$$
\mathrm{Z}=\mathrm{A}-\mathrm{B} \text {. }
$$

\section{Z- Temporary differences}

A- Unrealized internal profit and loss originated from internal tractions.

B- All kinds of cumulative reserves corresponding to factor A, such as inventory falling price reserves [3,5], impairments of this fixed assets [4, 5], bad debt reserves [5], etc.

Notes for Eq. 1: (1) it can be used to calculate temporary differences arise from internal inventories, fixed assets and Acc receivable\& payable transactions; (2) all kinds of cumulative reserves corresponding to factor A are illusive reserves from the group company's angle except the real ones; (3) both factor A and factor B will occur in internal inventories or fixed assets tractions, if not, the corresponding factor value is zero; (4) in dealing with internal receivable\& payable accounts, factor A equals to zero and factor B equals to the sum of bad debt reserves. 


\section{Principles of the formula}

It's known that deferred income tax assets or liabilities equal to temporary differences, which arise from the differences between accounting book value and tax base stipulated by the corporate income tax law and the differences do not change because of offset entries in combining balance sheet, multiplied by the income tax rate. If the increment of deferred income tax liabilities minus the increment of deferred income tax assets is positive (negative), the spread is deferred income tax expenses (deferred income tax returns) that will be a part of income tax expenses.

In the internal tractions, tax base can be defined by the entry value of the buyer or the selling price of the seller. If the seller gets profits, accounting book value of the group company's assets counted at the internal sale cost $[1,6]$ will be lower than the tax base, so the book value minus tax base (great than zero) will form a deductible temporary difference, and then, it will evolve into deferred income tax assets.

Under another condition, in the internal tractions, tax base can be still defined by the entry value of the buyer or the selling price of the seller. If the seller suffers losses, accounting book value of the group company's assets counted at the internal sale cost will be higher than the tax base, so the book value minus tax base (less than zero) will form a taxable temporary difference, and then, it will evolve into deferred income tax liabilities.

\section{Calculating procedure}

Offset entries for the deferred income tax assets or liabilities can be processed according to the following steps in the course of balance sheet Consolidation.

\section{Judgments for deferred income tax assets or liabilities}

From the angle of internal seller, if the profits are positive, then the deferred taxes will be deferred tax assets; on the contrary, it will be deferred tax liabilities.

\section{Confirm the beginning\& ending Temporary differences}

For the specified accounting period, we can calculate the beginning temporary differences $\left(Z_{\text {year-b }}\right)$ and the ending temporary differences(year-e) by using Eq. 1; Actually, there is no necessity to confirm auxiliary offset entries as foundations before you can computerize any offset entries amount for any given time point.

\section{Temporary differences increments}

The Temporary differences increments can be the Eq. 2 .

$$
\Delta \mathrm{Z}_{\text {year }}=\mathrm{Z}_{\text {year-b }}-\mathrm{Z}_{\text {year-e }} \text {. }
$$

\section{Sum of deferred tax assets or liabilities}

If the corporate income tax rate is $\mathrm{T}$, the sum of deferred tax assets or deferred tax liabilities can be the Eq. 3.

$$
\mathrm{D}=\left|\Delta \mathrm{Z}_{\mathrm{year}} * \mathrm{~T}\right|
$$

\section{Offset entries for given time point}

For any point in time, the offset entries can be classified as Table 1 
Table 1 Types of offset entries for deferred taxes assets or liabilities

\begin{tabular}{|c|c|c|}
\hline \multirow{2}{*}{ Deferred taxes } & \multicolumn{2}{|c|}{ Temporary differences increments } \\
\cline { 2 - 3 } & $\Delta \mathrm{Z}_{\text {year }}>0$ & $\Delta \mathrm{Z}_{\text {year }}<0$ \\
\hline Deferred income tax assets & $\begin{array}{c}\text { Debit: } \\
\text { Credit: } \\
\text { Deferred income tax assets D }\end{array}$ & $\begin{array}{c}\text { Credit: } \\
\text { Deferred income tax assets D }\end{array}$ \\
\hline $\begin{array}{c}\text { Deferred income tax } \\
\text { liabilities }\end{array}$ & $\begin{array}{c}\text { Debit: } \\
\text { Defered income tax } \\
\text { liabilities D }\end{array}$ & $\begin{array}{c}\text { Deferred income tax } \\
\text { liabilities D }\end{array}$ \\
\hline
\end{tabular}

\section{Numerical examples}

\section{An example for internal inventory traction}

Company Alpha has $80 \%$ stake in company U, in 2011, company U purchased from company Alpha 200 pieces of goods X, the price (cost) was RMB 0.05 million (0.03) per piece, and sold 150 pieces of them at the price of RMB 0.05 million for each. At the year end, the net realizable value of each piece was RMB 0.036 million. In 2012, company U sold 30 pieces of $X$ at the price of RMB 0.029 million for each. At the ending, the net realizable value of each piece was RMB 0.028 million. The income tax rate was $25 \%$ for both sides.

Requirement: please analyze the amounts of deferred taxes in each of the offset entries for year 2012.

Analysis for year 2011. At the beginning: $Z_{2011-b}=0$. At the ending: according to the Eq. 1 and Table 1 , factor $\mathrm{A}=(200-150) *(0.05-0.03)=1$, factor $\mathrm{B}=(200-150) *(0.05-0.036)=0.7$ (the inventory falling price reserves were illusive as the net realizable value 0.036 was greater than the cost 0.03 ), $\mathrm{Z}_{2011-\mathrm{e}}=\mathrm{A}-\mathrm{B}=1-0.7=0.3, \Delta \mathrm{Z}_{2011}=0.3-0=0.3$, deferred tax assets $=0.3 * 0.25=0.075$. We can debit the deferred income tax assets $(0.75)$, credit undistributed profits $(0.75)$. (Handling the accounts of last year)

Analysis for year 2012. At the beginning: $Z_{2012-\mathrm{b}}=Z_{2011-\mathrm{e}}=0.3$. At the ending: factor $\mathrm{A}=(200-150-30) *(0.05-0.03)=0.4$, factor $\mathrm{B}=0.02 * 20=0.4$ (the total falling price reserves for each piece $=$ the false parts + the real parts, the total $=3-2.8=0.2$, the false parts $=3-2.8=0.2$, so the real parts $=2.2-0.2=2, \mathrm{Z}_{2012-\mathrm{e}}=\mathrm{A}-\mathrm{B}=0, \Delta \mathrm{Z}_{2012}=0-0.3=-0.3$, deferred tax assets $=0.3 * 0.25=0.075$. We can debit the income tax expenses (0.075), credit the deferred income tax assets (0.075).

\section{An example for internal fixed assets traction}

On June 15, 2011, public company Beta sold a fixed asset with the book value of RMB 2 million to its subsidiary company V at the price of RMB 2.5 million. After buying that, company V used it as a fixed asset for the purpose of management department use with the book value RMB 2.5 million. This asset could be still used for 5 years and the expected net salvage value was zero. Company V adopted the straight-line depreciation method and at the end of 2013 the recoverable amount of this asset would be RMB 1 million, income tax rate was $25 \%$.

Requirement: please analyze the amounts of deferred taxes in each of the offset entries for year 2011 and year 2013.

Analysis for year 2011. At the beginning: $Z_{2011-b}=0$. At the ending: the seller's earned RMB 0.5 million did not be realized from the outside perspective of the group company in this internal traction, which would be realized through depreciation yearly. In 2011, some profits came true through half year's depreciation. According to the Eq. 1 and Table 1 , factor $A=0.5 *(5-0.5) / 5=0.45$, factor $\mathrm{B}=0$ (no impairments of this fixed asset), $\mathrm{Z}_{2011-\mathrm{e}}=\mathrm{A}-\mathrm{B}=0.45-0=0.45, \Delta \mathrm{Z}_{2011}=0.45-0=0.45$, deferred tax assets $=0.45 * 0.25=0.1125$. We can debit the deferred income tax assets $(0.1125)$, credit the income tax expenses $(0.1125)$.

Analysis for year 2012. At the beginning: $Z_{2012-\mathrm{b}}=Z_{2011-\mathrm{e}}=0.45$. At the ending: factor $\mathrm{A}=0.5^{*}(5-1.5) / 5=0.35$ (depreciation for 1.5 years), $\mathrm{B}=0$ (no impairments of this fixed asset), 
$\mathrm{Z}_{2012-\mathrm{e}}=\mathrm{A}-\mathrm{B}=0.35, \Delta \mathrm{Z}_{2012}=0.35-0.45=-0.1$, deferred tax assets $=0.1 * 0.25=0.025$. We can debit the income tax expenses (0.025), credit the deferred income tax assets $(0.025)$.

Analysis for year 2013. At the beginning: $Z_{2013-\mathrm{b}}=Z_{2012-\mathrm{e}}=0.35$. At the ending: factor $\mathrm{A}=0.5 *(5-2.5) / 5=0.25$ (depreciation for 2.5 years), factor $\mathrm{B}=0.25$ (book value from the buyer's perspective $=2.5 *(5-2.5) / 5=1.25$; book value from the group company's perspective $=2.0 *(5-2.5) / 5=1.0$; so the real impairments of this fixed asset were zero and the impairments book kept by the buyer were false), $\mathrm{Z}_{2013-\mathrm{e}}=\mathrm{A}-\mathrm{B}=0, \quad \Delta \mathrm{Z}_{2013}=0-0.35=-0.35$, deferred tax assets $=0.35 * 0.25=0.0875$. We can debit the income tax expenses $(0.0875)$, credit the deferred income tax assets (0.0875).

\section{An example for receivable \& payable accounts}

On January 1, 2012, company Gamma had 80\% stake in company W, on December 31, 2012, company Gamma's balance of accounts receivable related to company W was RMB 3 million (Beginning balance was zero), company Gamma adopted Percentage of total accounts receivable method to make provision for bad debts at 5\%; At the end of 2013 Gama's accounts receivable balance related to company W was RMB 4 million, the income tax rate was $25 \%$ for both sides.

Requirement: please analyze the amounts of deferred taxes in each of the offset entries for year 2012 and year 2013.

Analysis for year 2012. At the beginning: $Z_{2012-b}=0$. At the ending: receivable\& payable accounts don't had relationship with unrealized internal profits or losses, and there were reserves for bad debts, so according to Eq. 1 and Table 1 , factor $A=0$, factor $B=300 * 0.05=15$, $\mathrm{Z}_{2012-\mathrm{e}}=\mathrm{A}-\mathrm{B}=0-15=-15, \Delta \mathrm{Z}_{2012}=-15-0=-15$, deferred tax assets $=15 * 0.25=3.75$. We can debit the income tax expenses (3.75), credit deferred income tax assets (3.75).

Analysis for year 2013. At the beginning: $Z_{2013-\mathrm{b}}=Z_{2012-\mathrm{e}}=-15$. At the ending: factor $A=0$, factor $\mathrm{B}=400 * 0.05=20, \mathrm{Z}_{2013}=\mathrm{A}-\mathrm{B}=0-20=-20, \Delta \mathrm{Z}_{2013}=-20-(-15)=-5$, deferred tax assets $=5 * 0.25=1.25$. We can debit the income tax expenses (1.25), credit deferred income tax assets (1.25).

\section{Summary}

Temporary differences originate from the differences between accounting standards and corporate income tax laws in China, which lead to the deferred taxes. The above discussion analyzed the temporary differences for any given point in time from the angle of the deferred taxes originating sources, so we can avoid some methods relying on merging amount of some specified entries that can derive temporary differences and then deferred tax assets or deferred tax liabilities.

Some other supplementary instructions are put forward here: this formula can be applied to not only the current period of the tractions, but also to the following periods. Actually, it can be used to calculate the sum of deferred taxes in offset entries at any point in time. The above example shows that the proposed new method has clear principles, concise steps, accurate calculation results and strong commonality. It will be helpful for beginners or practitioners to confirm the sum of the deferred taxes in offset entries in balance sheet consolidation quickly.

\section{Acknowledgement}

This research was financially supported by both the Education Department of Sichuan Province (Project No. 630.40) and the Yinxing Hospitality Management College.

\section{References}

[1] Ministry of Finance, P. R. China, Accounting Standard for Business Enterprises: No.33-Consolidated Financial Statements, Economic Science Press, Beijing, (2006)

[2] Ministry of Finance, P. R. China, Accounting Standard for Business Enterprises: No.18-Income Taxes, Economic Science Press, Beijing, (2006) 
[3] Ministry of Finance, P. R. China, Accounting Standard for Business Enterprises: No.1-Inventories, Economic Science Press, Beijing, (2006)

[4] Ministry of Finance, P. R. China, Accounting Standard for Business Enterprises: No.4-Fixed Assets, Economic Science Press, Beijing, (2006)

[5] Ministry of Finance, P. R. China, Accounting Standard for Business Enterprises: No.8-Impairment of Assets, Economic Science Press, Beijing, (2006)

[6] Ministry of Finance, P. R. China, Accounting Standard for Business Enterprises: No.30-Presentation of Financial Statements, Economic Science Press, Beijing, (2006) 